\title{
Analysis of the rate of restenosis in patients with acute coronary syndrome without ST elevation and concomitant diabetes mellitus type 2 according to the kind of stent
}

Analiza częstości występowania restenozy u chorych z ostrym zespołem wieńcowym bez uniesienia odcinka ST i ze wspólistniejącą cukrzycą w zależności od rodzaju implantowanego stentu

\section{Jan Zbigniew Peruga, Radosław Kręcki, Maria Krzemińska-Pakuła}

II Department and Clinic of Cardiology, Medical University of Lodz, Poland

Post Kardiol Interw 2011; 7, 3 (25): 206-213 DOI: 10.5114/pwki.2011.24737

\begin{abstract}
Background: Acute coronary syndrome without ST segment elevation (NSTEMI) in patients with diabetes mellitus (DM) has poor prognosis and percutaneous coronary intervention $(\mathrm{PCI})$ is the best treatment strategy. However, there are no clear guidelines concerning the choice of optimal invasive treatment strategy.

Aim: To evaluate the restenosis rate in patients with NSTEMI and DM depending on the kind of implanted stent.

Material and methods: The study group comprised 984 NSTEMI patients hospitalized in the 2nd Department of Cardiology. 352 patients received a bare metal stent (BMS), while 632 pts received a drug-eluting stent (DES) -238 pts a paclitaxel-eluting stent (PES) and 394 a sirolimus-eluting stent (SES). There were no statistically significant differences concerning age of the groups.

Results: After 1-year follow-up there were no significant mortality differences $-7.9 \%$ in the BMS group, $8.8 \%$ in the PES group and $8.1 \%$ in the SES group. There were 6 in-hospital deaths, one in the BMS and PES groups and 4 in the SES group. After 1-year follow-up there were significant restenosis rate differences: $8.24 \%$ in the BMS group, $8.4 \%$ in the PES group and $6.34 \%$ in the SES group $(p=0.003)$. Stent thrombosis was a rare complication and occurred in 10 patients without differences in stent groups. The predictors of restenosis revealed by univariate logistic regression analysis included female gender, lipid disturbances $(p<0.001)$, past myocardial infarction $(p<0.001)$ and peripheral arterial disease $(p<0.001)$.

Conclusions: Percutaneous coronary angioplasty in patients with NSTEMI and coexisting DM is effective and safe. Implantation of sirolimus-eluting stents gives the best long-term results expressed as the lowest restenosis rate.
\end{abstract}

Key words: acute coronary syndrome without ST segment elevation, diabetes mellitus, percutaneous coronary intervention, bare metal stent, drug-eluting stent

\section{Streszczenie}

Wstęp: Ostry zespół wieńcowy bez uniesienia odcinka ST (ang. non ST elevation myocardial infarction, NSTEMI) u pacjentów ze wspótistniejącą cukrzycą obarczony jest gorszym rokowaniem, a leczenie pierwotną angioplastyką okazuje się najkorzystniejszą metodą leczniczą. Mimo wielu badań poświęconych leczeniu chorych z NSTEMI, nie ma szerszych opracowań dotyczących wyboru strategii leczenia inwazyjnego osób z NSTEMI i towarzyszącą cukrzycą.

Cel: Analiza częstości występowania restenozy w zależności od rodzaju implantowanego stentu.

Materiał i metody: Badaniem objęto kolejnych 984 chorych hospitalizowanych w Klinice Kardiologii z powodu NSTEMI ze współistniejącą cukrzycą. Stent metalowy (ang. bare metal stent, BMS) miało wszczepiony 352 chorych, a 632 - stent uwalniający lek, w tym 238 pokryty paklitakselem (ang. paclitaxel eluting stent, PES), a 394 sirolimusem (ang. sirolimus eluting stent, SES). Nie stwierdzono różnic dotyczących średniej wieku osób w grupach leczonych przezskórną angioplastyką wieńcową (ang. percutaneous coronary intervention, $\mathrm{PCl})$, które otrzymały BMS.

Wyniki: W obserwacji szpitalnej odnotowano łącznie 6 zgonów, w tym po 1 w grupach osób z BMS i PES oraz 4 w grupie osób z SES. Podczas rocznej obserwacji śmiertelność nie różniła się w poszczególnych grupach i wynosiła 7,9\% w grupie osób z BMS, 8,8\% w grupie osób z PES i 8,1\% w grupie osób z SES. W obserwacji rocznej odsetek chorych z nawrotem zwężenia w grupie z implanto-

Corresponding author/Adres do korespondencji:

Jan Zbigniew Peruga MD, PhD, II Department and Clinic of Cardiology, Medical University of Lodz, 1/5 Kniaziewicza, 91-347 Lodz, Poland, tel.: +48 4225160 15, fax: +48 4265399 09, e-mail: jzperuga@ptkardio.pl

Praca wpłynęła: 9.08.2011, przyjęta do druku: 30.08.2011. 
wanym BMS wynosił 8,24\%, a z PES 8,4\%. Zwraca uwagę rzadziej występująca restenoza w grupie osób z implantowanym SES (6,34\%, $p=0,003)$. Zakrzepica w stencie zdarzała się stosunkowo rzadko i obserwowano ją łącznie u 10 chorych w podobnym odsetku w grupie osób z BMS, PES i SES. W analizie rocznej i odległej czynnikami ryzyka wystąpienia restenozy okazały się płeć żeńska, zaburzenia lipidowe $(p<0,001)$, przebyty zawał serca $(p<0,001)$ oraz choroba naczyń obwodowych $(p<0,001)$.

Wnioski: Przezskórna angioplastyka wieńcowa jest skuteczną i bezpieczną metodą rewaskularyzacji chorych z NSTEMI i współistniejącą cukrzycą. Analiza materiału w obserwacji rocznej nie wykazała istotnej przewagi PES nad BMS. Istotne statystycznie różnice wykazano dla SES, natomiast w obserwacji odległej zaznaczyła się wyraźna przewaga stentów uwalniających leki wyrażająca się znacznie mniejszą częstością występowania restenozy w tych grupach pacjentów.

Słowa kluczowe: ostry zespół wieńcowy bez uniesienia odcinka ST, cukrzyca typu 2, angioplastyka wieńcowa, klasyczne stenty metalowe, stenty uwalniające leki

\section{Introduction}

Patients with diabetes mellitus (DM) have more advanced changes in the coronary arteries and more frequent presence of multivessel disease affecting two or more arteries, including the left main coronary artery [1]. For that reason, surgical revascularization was considered as the method of choice in this group of patients. The efficacy of percutaneous coronary intervention (PCI) procedures may be limited by a high rate of restenosis, difficulties in obtaining full revascularization of the ischaemic area and/or fast progression of atherosclerosis in vessels treated with angioplasty and in other vessels [2]. Patients with diabetes have a higher risk of restenosis, particularly in the long-term observation. Therefore the correct choice of stent is an important issue. Results of the RAVEL and SIRIUS trials confirmed a decrease of the restenosis rate (0-16\%) for the rapamycin-coated stent in the subgroup of patients with DM in comparison to $42-51 \%$ observed after implantation of bare metal stents $[3,4]$. Similar benefits of treatment in patients with DM were demonstrated with the use of paclitaxel-coated stents in the TAXUS trial [5]. The question is whether the choice of stent (bare metal [BMS] or drug-eluting) influences the longterm prognosis and particularly mortality or restenosis rate in high risk patients, such as those with coexisting diabetes.

\section{Aim}

The aim of the study was to analyse the frequency of restenosis in one-year and long-term observation according to the type of implanted stent.

\section{Material and methods}

The analysis included 984 consecutive patients with diabetes hospitalized in the Department of Cardiology due to acute coronary syndrome without persistent ST-segment elevation who were treated with primary angioplasty. More detailed data are presented in table 1 . All patients met the following inclusion criteria:

- the presence of electrocardiogram (ECG) changes on admission such as ST-segment depression in more than one lead or dynamic of ST-segment changes,

Table 1. Analysis of patients who underwent PCI - clinical data

Tabela 1. Analiza chorych poddanych PCl-dane kliniczne

\begin{tabular}{|c|c|c|c|c|}
\hline Type of stent & BMS 352 & PES 238 & SES 394 & Value of $p$ \\
\hline Age [years] & $60.4[55.2,68]$ & $59.2[54.7,69.5]$ & $61.2[54.7,70.5]$ & $>0.05$ \\
\hline Sex (male \%) & $59.0 \%(208 / 352)$ & $65.1 \%(155 / 238)$ & $61.2 \%(241 / 394)$ & $>0.05$ \\
\hline $\mathrm{BMI}\left[\mathrm{kg} / \mathrm{m}^{2}\right]$ & $28.1(26.8,30.1)$ & $25.5(24.2,29.2)$ & $27.7(25.0,31.2)$ & $>0.05$ \\
\hline History of myocardial infarction [\%] & $9.5(34 / 352)$ & $10.0(24 / 238)$ & $9.6(38 / 394)$ & $>0.05$ \\
\hline Hypertension [\%] & $48.0(169 / 352)$ & $49.6(118 / 238)$ & $48.2(190 / 394)$ & $>0.05$ \\
\hline Dyslipidaemia [\%] & $38.0(134 / 352)$ & $47.0(112 / 238)$ & $39.6(156 / 394)$ & $>0.05$ \\
\hline Smoking [\%] & $36.4(128 / 352)$ & $40.3(96 / 238)$ & $40.8(161 / 394)$ & $>0.05$ \\
\hline Diabetes treated with insulin [\%] & $30.96 \%(109 / 352)$ & $33.61 \%(80 / 238)$ & $32.48 \%(128 / 394)$ & $>0.05$ \\
\hline Glycated haemoglobin level $\left(\mathrm{HbA}_{1 \mathrm{c}}\right)$ & $7.6 \pm 2.1$ & $7.0 \pm 1.9$ & $7.4 \pm 2.2$ & $>0.05$ \\
\hline Renal failure & $3.98 \%$ & $3.4 \%$ & $3.55 \%$ & $>0.05$ \\
\hline $\mathrm{GFR}<60 \mathrm{ml} / \mathrm{min}$ & $14 / 352$ & $8 / 238$ & $14 / 394$ & \\
\hline Previous $\mathrm{PCI}$ or $\mathrm{CABG}[\%]$ & $9.65(34 / 352)$ & $9.82(21 / 238)$ & $9.98(39 / 394)$ & $>0.05$ \\
\hline $\begin{array}{l}\text { Heart failure \% } \\
\text { NYHA class III or more }\end{array}$ & $\begin{array}{c}2.27 \\
(8 / 352)\end{array}$ & $\begin{array}{c}2.94 \\
(7 / 238)\end{array}$ & $\begin{array}{c}2.53 \\
(10 / 394)\end{array}$ & $>0.05$ \\
\hline Peripheral arterial disease [\%] & $3.97(14 / 352)$ & $4.62(11 / 238)$ & $3.04(12 / 394)$ & $>0.05$ \\
\hline Ejection fraction < 45\% [\%] & $21.02(74 / 352)$ & $19.32(46 / 238)$ & $21.31(84 / 394)$ & $>0.05$ \\
\hline
\end{tabular}


- increased concentration of myocardial necrosis markers - troponin or CK-MB,

- the presence of diabetes diagnosed before admission or during hospitalization with routinely used laboratory methods.

All patients underwent coronary angiography and echocardiographic examination with the assessment of ejection fraction (EF) and the degree of contraction abnormalities.

Three hundred and fifty-two patients received a bare metal stent and 632 had a drug-eluting stent implanted (paclitaxel coated [PES] in 238 cases and sirolimus coated [SES] in 394 cases). After discharge patients remained under ambulatory follow-up.

\section{Statistical analysis}

All qualitative data are presented as absolute numbers and percentages. Continuous variables are presented as means or medians. The data distribution is presented as the standard deviation with minimal and maximal values provided.

Statistical analysis of the studied variables was based on the parametric and non-parametric tests. Analysis of the empirical distributions of studied parameters was performed using the Shapiro-Wilk W test. The KruskalWallis test was performed to compare the control group and studied groups. The following non-parametric tests were applied to verify the hypothesis that two qualitative features in the population are independent:

$-\chi^{2}$ Pearson's test for qualitative variables,

$-\chi^{2}$ test with Yates' correction,

- Fisher's exact test [7].

All calculations were performed using Statistica ver. 8.0 PL.

\section{Results}

Table 1 shows that groups of patients who received BMS, PES or SES were similar in relation to age, percentage of men, risk factors, the frequency of ejection fraction below $45 \%$ and the frequency of coexisting peripheral arterial disease or previous surgical or percutaneous revascularization.

There was no difference in age between the $\mathrm{PCl}$ groups (BMS/PES/SES). The percentage of men was similar (between 59\% and 65.1\%) and this sex predominated in all groups.

The prevalence of other risk factors such as hypertension, dyslipidaemia, and previous myocardial infarction was also comparable. The percentage of smokers was high in all groups and varied between $36.4 \%$ and $40 \%$, with the highest proportion observed in patients with SES. However, this difference was not statistically significant. Other clinical parameters were also similar: the percentage of patients on insulin, glycated haemoglobin level $\left(\mathrm{HbA}_{1 \mathrm{c}}\right)$ or renal failure.

Data regarding $\mathrm{PCl}$ procedures are presented in table 2 . The procedure was performed immediately after coronary angiography in approximately $90 \%$ of patients in all analysed groups. In most cases, only one vessel was treated (mean 1.03 to 1.08 vessels). TIMI flow 0/1 before $\mathrm{PCl}$ was present in almost $70 \%$ of patients. TIMI III flow after $\mathrm{PCl}$ was observed in $90 \%$ of patients.

The degree of stenosis was highest in the SES group (97\%) in comparison to the PES group (88.2\%) and BMS group $(92.8 \%)(p<0.05)$. The reference vessel diameter was highest in the BMS group (2.98) and lowest in the PES group (2.73); $p<0.05$. GP IIb/IIla inhibitors and heparin were used in a similar percentage of patients before the

Table 2. Data regarding interventional treatment $(\mathrm{PCI})$

Tabela 2. Dane dotyczace leczenia zabiegowego (PCI)

\begin{tabular}{|c|c|c|c|c|}
\hline Type of stent & BMS 352 & PES 238 & SES 394 & Value of $p$ \\
\hline Procedure immediately after coronary angiography & $94.3(332)$ & $89.0(212)$ & $94.4(376)$ & $>0.05$ \\
\hline Number of treated vessels (mean) & 1.08 & 1.03 & 1.06 & $>0.05$ \\
\hline TIMI flow before $\mathrm{PCI}$ TIMI 0/I & $69.9(246)$ & $58.0(138)$ & $68.8(271)$ & $>0.05$ \\
\hline TIMI II & $18.2(64)$ & $25.6(61)$ & $20.8(82)$ & $>0.05$ \\
\hline TIMI III & $11.9(42)$ & $16.4(39)$ & $10.4(41)$ & $>0.05$ \\
\hline Reference diameter of the vessel & $2.98(2.55-3.45)$ & $2.73(2.47-3.18)$ & $2.88(2.55-3.22)$ & $<0.05$ \\
\hline Degree of stenosis [\%] & $92.8(75.0-100.0)$ & $88.8(74.0-100.0)$ & $97.0(76.9-100.0)$ & $<0.05$ \\
\hline Number of implanted stents & 1.09 & 1.07 & 1.04 & $>0.05$ \\
\hline Length of implanted stent/stents & $22.0(10-24)$ & $25.0(10-32)$ & $24.6(10-33)$ & $>0.05$ \\
\hline Heparin administered before the procedure [\%] & 50.5 & 50.5 & 54.4 & $>0.05$ \\
\hline 300 mg clopidogrel dose before PCI [\%] & 32 & 28 & 31 & $>0.05$ \\
\hline 600 mg clopidogrel dose before PCI [\%] & 68 & 72 & 69 & $>0.05$ \\
\hline Use of GP IIb/IIla inhibitors [\%] & 27 & 26 & 28 & $>0.05$ \\
\hline TIMI III after $\mathrm{PCl}$ & $92(324)$ & $93(221)$ & $90.1(358)$ & $>0.05$ \\
\hline
\end{tabular}


procedure. There were also no significant differences in the frequency of clopidogrel loading with $300 \mathrm{mg}$ and $600 \mathrm{mg}$.

Data regarding the procedure and in-hospital observation are illustrated in table 3 . There were 6 deaths during hospitalization including 1 in the BMS group, 1 in the PES group and 4 in the SES group. Local bleeding complications requiring surgical intervention or blood transfusion were quite frequent. The frequency of those complications was significantly lowest in the SES group.

\section{One-year observation}

One-year observation demonstrated similar mortality between studied groups (7.9\% in the BMS group, $8.8 \%$ in the PES group and $8.1 \%$ in the SES group), as demonstrated in table 4 . Notably there was a lower restenosis rate in the SES group $-6.34 \%(p=0.003)$. Stent thrombosis was relatively infrequent - it occurred in 10 patients and the rate was similar in the BMS, PES and SES group.

One-year analysis of patients with restenosis (tab. 5) demonstrated a higher proportion of women $(55.4 \%$, $p<0.001)$, higher frequency of dyslipidaemia $(56.76 \%$, $p<0.001)$ and previous myocardial infarction (41.89\% vs. $8.16 \%, p<0.001)$, higher prevalence of heart failure NYHA class III $(9.46 \%$ vs. $1.96 \%, p<0.001)$, and more diffuse atherosclerosis as expressed by higher prevalence of peripheral arterial disease ( $21.62 \%$ vs. $2.29 \%, p<0.001)$. Other risk factors such as smoking were also more frequent in this group of patients $(58.11 \%$ vs. $37.21 \%, p<0.01)$.

Interestingly, there was no difference in the restenosis rate between BMS and PES in 1-year observation (8.24\% vs. $8.4 \%)$, but there was a difference in the SES group (6.34\%), $p=0.003$ - figure 1.

It should be noted that female sex was a risk factor of restenosis at 1 year. The restenosis rate was $10.8 \%$ in women and $5.46 \%$ in men, which was statistically significant $(p<0.001$, odds ratio 1.98) - figure 2 .

\section{Long-term observation}

The mean time of observation in each group exceeded 3.5 years and was longest in the BMS group -4.46 years (maximally 10 years) (tab. 6). Mortality in the BMS group was $16.8 \%$, in the PES group $19.3 \%$ and in the SES group $15.9 \%$, which was not statistically significant. Angiographically proven restenosis was documented in $18.75 \%$ of patients in the BMS group, $12.18 \%$ in the PES group and $11.42 \%$ in the SES group.

Restenosis was noted in 140 patients in the long-term observation (tab. 7). Risk factors predisposing to a late recurrence of stenosis were analysed. As in 1-year observation, patients with restenosis were more likely to have previous myocardial infarction (30\% vs. $5.45 \%, p<0.001$ ), heart failure $(15 \%$ vs. $0.47 \%, p<0.001)$, renal failure $(21.43 \%$

Table 3. Data regarding effectiveness of interventional treatment $(\mathrm{PCl})$ - in-hospital observation

Tabela 3. Dane dotyczące skuteczności leczenia zabiegowego (PCI) - obserwacja wewnątrzszpitalna

\begin{tabular}{lcccc} 
Type of stent & BMS 352 & PES 238 & SES 394 & Value of $p$ \\
\hline TIMI III after PCI & $92(324 / 352)$ & $93(221 / 238)$ & $90.1(358 / 394)$ & $>0.05$ \\
\hline Periprocedural myocardial infarction & $0.57 \%(2 / 352)$ & $1.26 \%(3 / 238)$ & $1.27 \%(5 / 394)$ & $>0.05$ \\
\hline $\begin{array}{l}\text { Local complications requiring surgical intervention } \\
\text { or blood transfusion }\end{array}$ & $10 / 352$ & $7 / 238$ & $12 / 394$ & $>0.05$ \\
\hline Local complications treated conservatively & $5.96 \%^{\times}(21 / 352)$ & $6.72 \%^{\times}(16 / 238)$ & $3.04 \%^{\times}(12 / 394)$ & $<0.05$ \\
\hline Cardiovascular death & $0 / 352$ & $1 / 238$ & $2 / 394$ & $>0.05$ \\
\hline Non-cardiovascular death & $1 / 352$ & $0 / 238$ & $2 / 394$ & $>0.05$
\end{tabular}

Table 4. One-year observation of the patients treated with $\mathrm{PCI}$

Tabela 4. Obserwacja roczna chorych leczonych metoda PCI

\begin{tabular}{lcccc} 
Type of stent & BMS 352 & PES 238 & SES 394 & Value of $p$ \\
\hline Lack of data & 9 & 8 & 7 & $>005$ \\
\hline Composite end-point MACE & $22.4 \%(79 / 352)$ & $25.6 \%(61 / 238)$ & $23.0 \%(91 / 394)$ & $>0.05$ \\
\hline Mortality & $7.9 \%(28 / 352)$ & $8.8 \%(21 / 238)$ & $8.1 \%(32 / 394)$ & $>0.05$ \\
\hline Myocardial infarction & $22 / 352$ & $16 / 238$ & $28 / 394$ & $>0.05$ \\
\hline Cardiovascular death & $21 / 352$ & $16 / 238$ & $23 / 394$ & $>0.05$ \\
\hline Non-cardiovascular death & $7 / 352$ & $5 / 238$ & $9 / 394$ & $>0.05$ \\
\hline Repeated coronary angiography & $29 / 352$ & $24 / 238$ & $31 / 394$ & $>0.05$ \\
\hline Stroke & $1 / 352$ & $0 / 238$ & $2 / 394$ & $>0.05$ \\
\hline Restenosis & $8.24 \%(29 / 352)$ & $8.4 \%(20 / 238)$ & $6.34 \%(25 / 394)$ & $<0.001$ \\
\hline Stent thrombosis & $0.85 \%(3 / 352)$ & $1.26 \%(3 / 238)$ & $1.01 \%(4 / 394)$ & $>0.05$
\end{tabular}


Table 5. Risk predictors of restenosis in one-year observation

Tabela 5. Czynniki predykcyjne wystąienia restenozy w obserwacji rocznej

\begin{tabular}{|c|c|c|c|c|c|}
\hline Parameters & $\begin{array}{l}\text { Restenosis present } \\
(n=74)\end{array}$ & Percentage & $\begin{array}{l}\text { Restenosis absent } \\
\quad(n=910)\end{array}$ & Percentage & $\begin{array}{l}\text { Significance } \\
\text { (value of } p \text { ) }\end{array}$ \\
\hline Age [years] & $58.3 \pm 5.1$ & - & $61.1 \pm 7.1$ & - & NS \\
\hline Women & 41 & 55.4 & 320 & 35.16 & $<0.001$ \\
\hline Men & 33 & 44.59 & 590 & 64.83 & $<0.01$ \\
\hline Hyperlipidaemia & 42 & 56.76 & 360 & 39.17 & $<0.001$ \\
\hline Hypertension & 26 & 35.14 & 451 & 49.08 & $<0.05$ \\
\hline Smoking & 43 & 58.11 & 342 & 37.21 & $<0.01$ \\
\hline Previous myocardial infarction & 31 & 41.89 & 75 & 8.16 & $<0.001$ \\
\hline Heart failure NYHA class III & 7 & 9.46 & 18 & 1.96 & $<0.001$ \\
\hline Renal failure & 13 & 17.57 & 23 & 2.50 & $<0.001$ \\
\hline Peripheral arterial disease & 16 & 21.62 & 21 & 2.29 & $<0.001$ \\
\hline Previous PCl & 31 & 41.89 & 63 & 6.86 & $<0.001$ \\
\hline
\end{tabular}

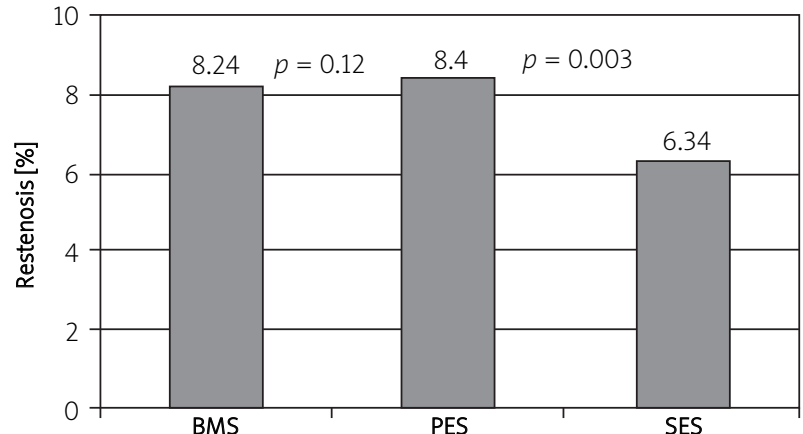

Fig. 1. Restenosis rate according to the type of implanted stent in one-year observation

Ryc. 1. Częstość występowania restenozy w obserwacji rocznej w zależności od rodzaju implantowanego stentu

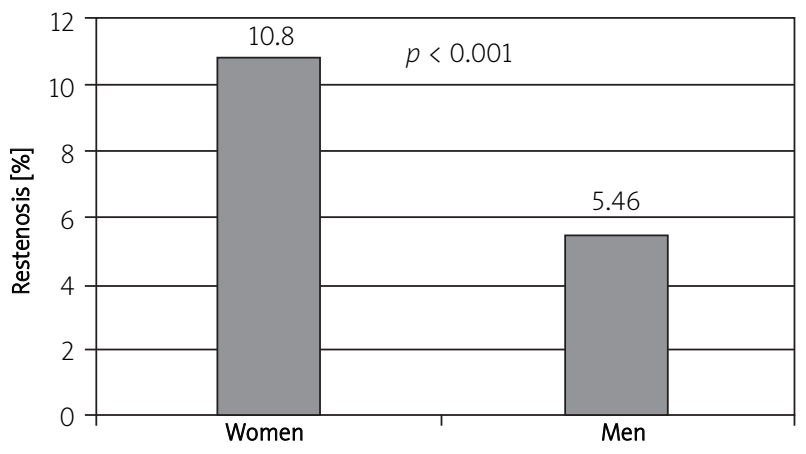

Fig. 2. Restenosis rate according to sex in one-year observation

Ryc. 2. Częstość występowania restenozy w obserwacji rocznej w zależności od płci

Table 6. Long-term observation of patients treated with $\mathrm{PCI}$ Tabela 6. Obserwacja odległa chorych leczonych metoda PCI

\begin{tabular}{lcccc} 
Type of stent & BMS 352 & PES 238 & SES 394 & Value of $p$ \\
\hline Remaining in observation & $268 / 352$ & $170 / 238$ & $290 / 394$ & $>0.05$ \\
\hline Mean time of observation & 4.46 & 3.64 & 3.72 & $<0.001$ \\
\hline Mortality & $16.8 \%(59 / 352)$ & $19.3 \%(46 / 238)$ & $15.9 \%(63 / 394)$ & $>0.05$ \\
\hline Myocardial infarction & $29 / 352$ & $17 / 238$ & $37 / 394$ & $>0.05$ \\
\hline Cardiovascular death & $27 / 352$ & $16 / 238$ & $29 / 394$ & $>0.05$ \\
\hline Non-cardiovascular death & $32 / 352$ & $30 / 238$ & $34 / 394$ & $>0.05$ \\
\hline Repeated coronary angiography & $56 / 352$ & $42 / 238$ & $57 / 394$ & $>0.05$ \\
\hline Stroke & $2.0 \%(7 / 352)$ & $5.04 \%(12 / 238)$ & $4.31 \%(17 / 394)$ & $>0.001$ \\
\hline Angiographically proven restenosis & $18.75 \%(66 / 352)$ & $12.18 \%(29 / 238)$ & $11.42 \%(45 / 394)$ & $<0.001$
\end{tabular}

vs. $0.71 \%, p<0.001)$, peripheral arterial disease (20\% vs. $1.07 \%, p<0.001)$ or repeated revascularizations ( $28.57 \%$ vs. $6.4 \%, p<0.001$ ). Dyslipidaemia was also more frequent in patients with late restenosis but this difference was less evident than in 1-year observation. There was no difference in the prevalence of hypertension and smoking.

It should be noted that there was a significant difference between the frequency of restenosis in women 
Table 7. Risk predictors of restenosis in the long-term observation

Tabela 7. Czynniki predykcyjne wystapienia restenozy w obserwacji odległej

\begin{tabular}{|c|c|c|c|c|c|}
\hline Parameters & $\begin{array}{l}\text { Restenosis present } \\
\quad(n=140)\end{array}$ & Percentage & $\begin{array}{l}\text { Restenosis absent } \\
\quad(n=844)\end{array}$ & Percentage & $\begin{array}{l}\text { Significance } \\
\text { (value of } p \text { ) }\end{array}$ \\
\hline Age [years] & 58.7 & & 61.1 & & \\
\hline Women & 82 & 58.57 & 298 & 35.31 & $<0.01$ \\
\hline Men & 58 & 41.43 & 546 & 64.69 & $<0.01$ \\
\hline Hyperlipidaemia & 81 & 57.86 & 321 & 38.03 & $<0.01$ \\
\hline Hypertension & 52 & 37.14 & 325 & 38.51 & NS \\
\hline Smoking & 65 & 46.43 & 320 & 37.91 & NS \\
\hline Previous myocardial infarction & 42 & 30.00 & 46 & 5.45 & $<0.001$ \\
\hline Heart failure NYHA class III & 21 & 15.00 & 4 & 0.47 & $<0.001$ \\
\hline Renal failure & 30 & 21.43 & 6 & 0.71 & $<0.001$ \\
\hline Peripheral arterial disease & 28 & 20.00 & 9 & 1.07 & $<0.001$ \\
\hline Previous PCl & 40 & 28.57 & 54 & 6.40 & $<0.001$ \\
\hline
\end{tabular}

and men $(21.58 \%$ in women and $9.6 \%$ in men - OR 2.25 , $p<0.001$ ) (fig. 3).

The restenosis rate was highest in patients with an implanted BMS (18.85\%) and lower in those with an implanted drug-eluting stent $(12.18 \%$ in the PES group and $11.42 \%$ in the SES group). The difference between patients with implanted BMS and drug-eluting stents was statistically significant. No differences were noted between drug-eluting stents (tab. 8, fig. 4). The frequency of restenosis was significantly higher in patients with BMS in comparison to patients with drug-eluting stents $(18.75 \%$ vs. $12.18 \%$ vs. $11.42 \%, p<0001)$. There was no significant difference between both types of drug-eluting stents $(12.8 \%$ vs. $11.42 \%, p<0.08)$.

\section{Discussion}

There are varying opinions regarding the choice of stent in NSTEMI patients with coexisting diabetes. However, as demonstrated by recently published studies and registries, most operators prefer DES [8-10]. It is accepted that implantation of DES is indicated primarily in patients at high risk (such as diabetic patients) and that those patients

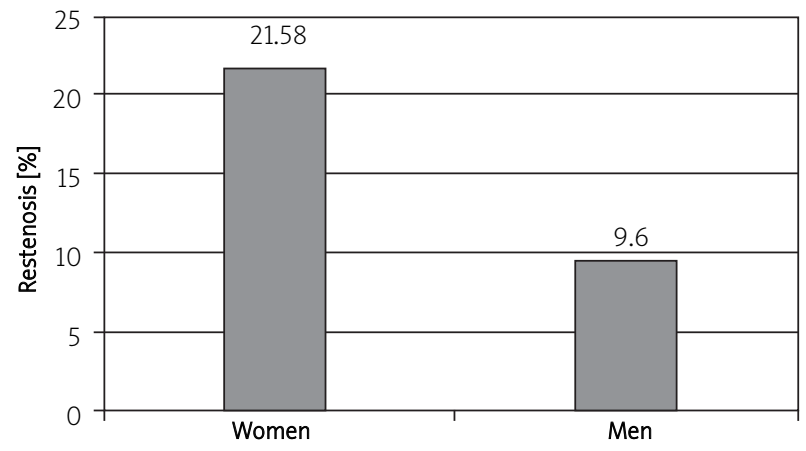

Fig. 3. Restenosis rate according to sex in the longterm observation

Ryc. 3. Częstość występowania restenozy w obserwacji odległej w zależności od ptci

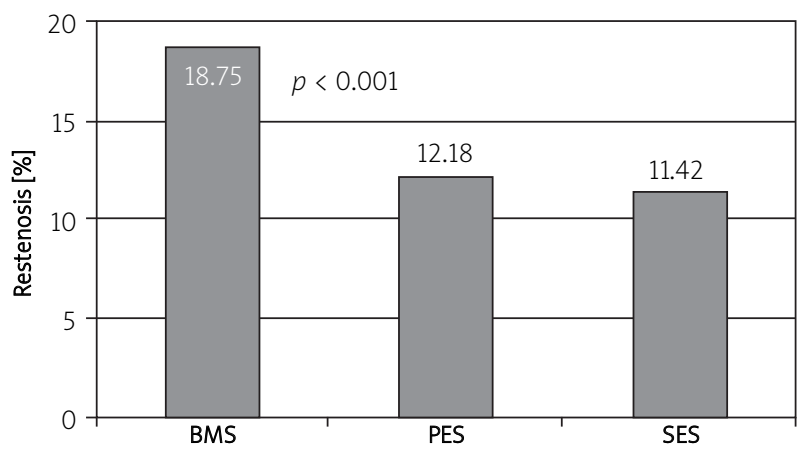

Fig. 4. Restenosis rate according to the type of implanted stent in the long-term observation

Ryc. 4. Częstość występowania restenozy w obserwacji odlegtej w zależności od rodzaju implantowanego stentu

Table 8. Restenosis rate according to the type of stent in the long-term observation

Tabela 8. Odsetek restenoz w zależności od rodzaju stentu w obserwacji odlegtej

\begin{tabular}{|c|c|c|c|c|c|}
\hline Stent & Restenosis present & Percentage & Restenosis absent & Percentage & Value of $p$ \\
\hline BMS (352) & 66 & 18.75 & 312 & 81.25 & $<0.001$ \\
\hline PES (238) & 29 & 12.18 & 209 & 87.82 & $<0.001$ \\
\hline SES (394) & 45 & 11.42 & 340 & 88.58 & $<0.001$ \\
\hline
\end{tabular}


benefit more in terms of for example lower restenosis rate [11]. In our material, 1-year mortality was comparable in BMS and DES groups and did not exceed $10 \%$ in any group.

The first analyses regarding the risk of restenosis in long-term observation in patients with implanted drugeluting stents were published approximately 6 years ago. The rate of restenosis was similar in the analysis of Corbertt et al., who studied cases of restenosis in 803 patients with sirolimus-eluting stents and in 1199 patients with paclitaxel-eluting stents after a mean of 1.5 years of observation [12]. There was a significant proportion of patients with diabetes in both compared groups $(30.6 \%$ for SES and $26.8 \%$ for PES). The authors performed an angiographic analysis of all patients and defined restenosis as more than $50 \%$ reduction of the vessel lumen in relation to the initial lumen diameter assessed directly after stent implantation in the stented area as well as $5 \mathrm{~mm}$ proximally and distally to the stent. Restenosis was observed in a relatively high proportion of patients - in $17.4 \%$ of those with an implanted PES and less frequently $(15.9 \%)$ in those with an implanted SES ( $p=0.509)$. Detailed angiographic analysis demonstrated that patients with an implanted PES have a significantly higher rate of diffuse restenosis, causing occlusion of the stented vessel (47.6\%) in comparison to $27.0 \%$ of those with an implanted SES $(p<0.001)$. Multivariable analysis demonstrated that diffuse restenosis occurred more frequently in women (odds ratio $\mathrm{OR}=3.994, p=0.003$ ). Female sex was the strongest predictive factor of diffuse restenosis. The type of stent (PES) was the second strongest factor $(\mathrm{OR}=2.693$, $p=0.002$ ). Also in our material female sex was a significant risk factor of restenosis. The differences were evident and regarded higher mortality and restenosis rate. This could have been influenced by many factors including anatomical conditions - smaller vessel lumen, higher vessel tortuosity, which could affect stent positioning, and efficacy of treatment.

The SCAAR registry including $\mathrm{PCI}$ procedures performed in Sweden between 2004 and 2008 comprised all patients who underwent invasive treatment in 26 large centres during that period [13]. The authors analysed 19004 patients, in whom 35478 stents were implanted during $22962 \mathrm{PCl}$ procedures. There were 8231 patients with diabetes in that group. The observation period for all patients was 2 years. Restenosis was defined as the presence of haemodynamically significant stenosis in patients undergoing repeated angiography due to the presence of clinical symptoms. The authors divided patients into 4 groups according to the type of implanted stent. Two groups included patients who underwent paclitaxel-eluting stent implantation (Taxus Express and Taxus Liberte) and the two other groups comprised patients who received sirolimus-coated stents (SES CYPHER) or stents coated with a compound of similar action - zotarolimus (ENDEAVOR). In all patients (including those with and without DM) implantation of a zotarolimuseluting stent led to a higher restenosis rate in comparison to other stents. The difference in restenosis rate was almost 2-fold in patients with DM and about 20-30\% in patients without DM in comparison to SES or PES. Notably, there was a relatively low difference in restenosis rate between patients with and without diabetes $-10 \%$ vs. $8.9 \%$ in 2-year observation - which are considerably different results from the results of other authors cited before. According to the authors, this difference might have been caused by an atypical course of coronary artery disease in patients with DM, who often do not have typical clinical symptoms used as the qualification criterion for a control coronary angiography. There were also no statistically significant differences in the frequency of restenosis in relation to the type of diabetes treatment (insulin vs. oral drugs).

It remains an open question whether there is a type of drug-eluting stent which would be particularly indicated in patients with DM. So far there is no unequivocal proof in clinical trials demonstrating superiority of any type of drug-eluting stents in patients with diabetes in the longterm observation. Most of the studies emphasize the superiority of drug-eluting stents over classic BMS. The results of the SIRIUS trials comparing the sirolimus-eluting stent and classic BMS after 9 months of observation in a subgroup of patients with diabetes showed a $17.6 \%$ restenosis rate in the case of SES and an almost 3-fold higher one $(50.5 \%)$ in the case of BMS implantation ( $p<0.001)$ [14]. There was also a $63 \%$ reduction of serious cardiac events in the SES group in comparison to the BMS group $(9.2 \%$ vs. $25 \%, p<0.001)$ after 270 days of observation. The TAXUS IV trial, which included $32 \%$ of patients with diabetes, compared the clinical and angiographic efficacy of treatment with paclitaxel-eluting stents or bare metal stents [15].

Angiographically proven restenosis was noted in $42.9 \%$ of diabetic patients treated with BMS and only in $7.7 \%$ of diabetic patients who received PES ( $p=0.007)$. Those studies arguably defined indications for drug-eluting stent implantation in patients with diabetes. However, it should be noted that both studies included clinically stable patients.

Can similar benefits be observed in the case of acute coronary syndromes? Our analysis demonstrated similar restenosis rates at 1 year in patients treated with BMS and PES (8.24\% vs. $8.4 \%, p=0.12)$ and lower frequency of restenosis in patients who received SES (6.34\%). However, more evident differences in the frequency of restenosis according to the type of implanted stent were noted in the long-term observation. Restenosis occurred more often in patients with BMS $(18.75 \%)$ in comparison to those who received PES (12.18\%) or SES (11.42\%) ( $p<0.001)$.

A notable fact confirmed in one-year and the long-term observation was a higher frequency of restenosis in 
women. During one year of observation in our group, restenosis occurred in $10.8 \%$ of women and in $5.46 \%$ of men $(p<0.0001)$. This phenomenon persisted and even increased in the long-term observation $(21.58 \%$ vs. $9.6 \%$, $p<0.001)$. This sex disequilibrium phenomenon was also confirmed by other researchers.

Risk factors predisposing to restenosis in one-year and the long-term observation included previous myocardial infarction, previous percutaneous revascularization, heart failure and renal failure as well as dyslipidaemia and peripheral arterial disease. Interestingly, in our group smoking was not a factor predisposing to restenosis in the long-term observation, which makes our results different from the results of other authors who demonstrated a negative influence of chronic smoking on the long-term prognosis (both in terms of higher risk of restenosis and mortality) [16]. This may be caused by the fact that the majority of patients refrained from smoking after $\mathrm{PCl}$ and had better blood pressure control after introduction of effective pharmacotherapy. On the other hand, renal failure and advanced heart failure (NYHA class III) had a significant influence on mortality and restenosis rate. The importance of those factors in the progression of restenosis was also emphasized by other authors $[17,18]$. Coexistence of peripheral arterial disease indicating more advanced atherosclerosis was another risk factor of death or restenosis.

\section{Conclusions}

Percutaneous coronary intervention is an effective and safe method of revascularization in patients with acute coronary syndrome without ST-segment elevation (NSTEMI) and with coexisting diabetes. The use of this method as a primary choice in this population of patients is justified by a high reperfusion rate (over $90 \%$ ) and a relatively low frequency of restenosis. Analysis of our material did not show a significant advantage of PES over BMS in 1-year observation. However, significant differences for SES were found. There was a marked advantage of drug-eluting stents in the long-term observation, as demonstrated by a significantly lower restenosis rate. Factors predisposing for restenosis were previous myocardial infarction, previous percutaneous revascularization, renal failure, heart failure and peripheral arterial disease.

\section{References}

1. Braunwald E. ACC/AHA guidelines for management of patients with unstable angina and non ST segment elevation myocardial infarction A report of the ACC/AHA Task Force on Practice Guidelines J Am Coll Cardiol 2000; 36: 970-1062.

2. Berger PB, Velianou JL, Vlachos HA, et al. Survival Following Coronary Angioplasty vs Coronary Artery Bypass Surgery in Anatomic subsets in which coronary artery bypass surgery improves survival compared with medical therapy. J Am Coll Cardiol 2001; 38: 1440-1449.

3. Morice MC, Serruys PW, Sousa JE, et al. Task for the Ravel Study Group. A randomized comparison of a sirolimus-eluting stent with a standard stent for coronary revascularization. N Engl J Med 2002; 346: 1780

4. Holmes DR Jr, Leon MB, Moses JW, et al. One year follow-up of the SIRIUS study: a randomized study with the sirolimus-eluting BX VELOCITY in the treatment of patients with de-novo native coronary artery lesions. J Am Coll Cardiol 2003; 41: 805-811.

5. Grube E, Silber S, Hauptmann KE, et al. Six-and twelve-month results from a randomized, double-blind trial on a slow-release paclitaxel-eluting stent for de novo coronary lesions. Circulation 2003; 107: 38.

6. Domański C. Testy statystyczne, PWE, Warszawa 1990.

7. Domański C, Iwaszkiewicz-Zasonka A, Jaszewski R, Zasonka J. Zastosowanie metod statystycznych $w$ badaniach pacjentów z chorobą niedokrwienną serca leczonych operacyjnie. Wydawnictwo Uniwersytetu tódzkiego, Łódź 2003.

8. Rosengren A, Wallentin L, Simoons W, et al. Age clinical presentation and outcomes of acute coronary syndromesin the Euroheart acute coronary syndrome survey. Eur Heart J 2006; 27 : 789-795.

9. Pell JP, Simson E, Rodger JC, et al. Impact of changing diagnostic criteria on incidence, management and outcome of acute myocardial infarction retrospective cohort study BMJ 2003; 326 : 134-135.

10. Norhammar A, Lagerqvist B, Saleh N. Long-term mortality after $\mathrm{PCl}$ in patients with diabetes mellitus: results from the Swedish Coronary Angiography and Angioplasty Registry. Eurolnterv 2010; 5: 891-897.

11. Loutf M, Marco J. Particularities of percutaneous coronary revascularization in diabetic patients the paris Course on revascularization Marco J. i wsp. red Europa Edition 2003; 173-91.

12. Corbertt SJ, Cosgrave J, Melzi G, et al. Patterns of restenosis after drug-eluting stent implantation: insights from a contemporary and comparative analisis of sirolimus and paclitaksel - eluting. Eur Heart J 2006; 27: 2330-2337.

13. Robert O, Lagerqvist B, Carlsson J, et al. Difference in restenosis rate with diference drug-eluting stents in patients with and without diabetes mellitus. A raport from SCAAR (Swedish Angiography and angioplasty Registry). J Am Coll Cardiol 2009; 53: 1660-1667.

14. Moussa I, Leon MB, Baim DS, et al. Impact of sirolimus eluting stents on outcome in diabetic patients: a SIRIUS (SIRolimUS coated Bx Velocity Balloon-expanded stent in the treatment of patients with de novo coronary leasion) substudy. Circulation 2004; 109: 2273-2278.

15. Stone GW, Ellis SG, Cox DA, et al. One-year clinical results with the slow-release polymer-based paclitaxel-eluting TAXUS stent: the TAXUS IV Trial. Circulation 2004; 109: 1942-1947.

16. Stone GW, Parise H, Witzenbichler B, et al. Selection criteria for drug-eluting versus bare-metal stents and the impact of routine angiographic follow-up: 2-year insights from the HORIZONS-AMI (Harmonizing Outcomes With Revascularization and Stents in Acute Myocardial Infarction) trial. J Am Coll Cardiol 2010; 56: 1597-1604.

17. Cutlip DE, Chauhan MS, Baim DS, et al. Clinical restenosis after coronary stenting. Perspectives from multicenter clinical trials. J Am Coll Cardiol 2002; 40: 2082-2089.

18. Abizaid A, Kornowski R, Mintz GS, et al. The influence of diabetes mellitus on acute and late clinical outcomes following coronary stent implantation. J Am Coll Cardiol 1998; 32: 584-589. 